\title{
A digitális hagyaték egyes szabályozási kihívásai, különös tekintettel az adatvédelmi aspektusokra
}

\author{
Some Legal Challenges of Digital Inheritance \\ with Special Regard to Privacy
}

\begin{abstract}
ABSZTRAKT
A digitális hagyaték komplexitása miatt jogilag egységesen nem megítélhető. A digitális hagyaték vagyoni jellegü elemeire az öröklési jog szabályai vonatkoznak, míg a személyiségi jellegü elemeire az adatvédelmi jog és a kegyeleti jog rendelkezései alkalmazandók. Hatályos jogrendszerünkben az információs önrendelkezési jogról szóló törvény módositása nyomán beemelésre került a hazai jogba az adatalany halála utáni személyes adatok védelme, valamint a kegyeleti jogok továbbra is biztosítják az adatalany emlékét sértő magatartás ellen a bírósághoz fordulás jogát.
\end{abstract}

Kulcsszavak: digitális hagyaték, halál utáni személyiségvédelem, személyes adat, adatvédelem, kegyeleti jog

\begin{abstract}
Digital inheritance, because of its complexity, cannot be considered uniformly. The elements of digital inheritance which can be considered as property are regulated by the law of succession. The personal elements of the digital inheritance are regulated by the right in memoriam and data protection laws. In the current Hungarian legal system the amendment of Act no. CXII of 2011 on the Right of Informational Self-Determination put the post-mortem privacy principle into regulatory form, in addition to the right to respect for the deceased which provides legal protection against violation of the memory of a deceased person.
\end{abstract}

Keywords: digital inheritance, post-mortem privacy, personal data, data protection, right to respect for the deceased

A technológia fejlődésével egyre inkább evidenciát jelent az online jelenlét, amely nem más, mint az egyén személyiségének a virtuális térben való megjelenése, az egyén online személyes adatainak összessége. Ez az online lét nem szűnik meg a halál pillanatában, a tartalmak akkor is elérhetőek maradnak, ha tulajdonosaik már nincsenek az élők sorában: az elhunytak úgynevezett digitális lenyomatot (digital footprint) - más szóval digitális maradványt ${ }^{1}$ vagy hagyatékot - hagynak maguk után. A digitális hagyaték és az öröklési jogi értelemben vett hagyaték között lehet

* Dr. Schubauer Petra PhD-hallgató, Károli Gáspár Református Egyetem Állam- és Jogtudományi Doktori Iskola; e-mail: petraschubauer@gmail.com. 
ugyan átfedés, a kettő mégsem azonos tartalmilag, ezért az elhunyt hátramaradt digitális adatainak kezelése dogmatikai kérdéseket vet fel.

Az „e-mmortality” (az immortality, azaz halhatatlanság szóból, ebben az értelemben: digitális halhatatlanság) korában szükségessé vált, hogy az elhunyt személyek személyiségi jogai és privátszférája védelemben részesülhessen. ${ }^{2}$ Szükséges foglalkoznunk a személyes adatok adatalany halála utáni sorsával, hiszen egyes számítások szerint a következő évtizedek során a közösségi média platformok sokkal inkább az elhunyt személyek, mint az élő személyek gyűjtőhelyévé válhatnak. Ezt a hipotézist támasztja alá az a tény, hogy a legismertebb közösségi média szolgáltató, a Facebook elhunyt felhasználóinak száma ugrásszerüen megnövekedett, és becslések szerint naponta mintegy nyolcezer felhasználója hal meg. ${ }^{3}$

A jogrendszernek állást kell foglalnia abban a kérdésben, hogy az elhunyt személyek adatait - mintegy digitális hagyatékát - miképp kezeli; mely jogterület szabályait hívja segítségül egy olyan társadalmi probléma kezeléséhez, amely a technológiai fejlődés (az internet tömeges elterjedése, a web2.0 szolgáltatások megjelenése, a közösségi média napi használata, az adatkezelések dinamikájának megváltozása stb.) eredményeképp merült fel. Fontos hangsúlyozni, hogy a kérdés megválaszolása komplex, holisztikus vizsgálatot igényel, és az alapvetően információs önrendelkezési joggal foglalkozó adatvédelem mellett több jogterület - így az öröklési jog, a személyiségi jogok és a szerződések joga is - érintett. Bár a jogi szabályozás próbálja tartani a lépést a technika rohamos fejlődésével, sajnálatos módon ez kevés sikerrel jár, mivel a jog a technológiánál jóval statikusabb, kevésbé dinamikus, így természetszerűleg mindig lassabban és nehezebben követi a technológiából eredő változásokat. ${ }^{4}$ Továbbá, a jogszabályok általában nem képesek a technológiákat teljes komplexitásukban, holisztikusan kódolni. ${ }^{5}$

Hatályos jogrendszerünkben a kegyeleti jogok, a vagyoni értékkel bíró, a digitális hagyaték részét képező elemek esetében az öröklési jog szabályai, esetlegesen a szellemi alkotások joga, valamint - mivel a digitális hagyatékban nagy méretú személyes adathalmaz is található - az adatvédelmi jog szabályai között találhatunk rendelkezéseket. Jelen tanulmány keretei között elsődlegesen az adatvédelmi jogi és polgári anyagi jogi vonatkozásokat kívánom bemutatni. A hagyatéki eljárásokra vonatkozó eljárási szabályozás ismertetése nem képezi a vizsgálat tárgyát.

${ }^{1}$ LUKÁcs Adrienn: Míg a halál el nem választ. Ars Boni, 2019. július 18. https://arsboni.hu/mig-a-halal-el-nemvalaszt/ (2021. 02. 14.).

${ }^{2}$ OLONI, Victoria: Life after death - Data protection rights of deceased persons. African Academic Network on Internet Policy, 2020. január 29. https://aanoip.org/life-after-death-data-protection-rights-of-deceasedpersons/ (2020. 09. 28.).

${ }^{3}$ Commission Nationale de l'Informatique et des Libertés: Mort numérique: peut-on demander l'effacement des information d'une personne décédée? 2020. október 28. https://www.cnil.fr/fr/mort-numerique-effacement-informations-personne-decedee (2021. 02. 05.).

${ }^{4}$ CSEH Gergely: A közösségi portálok árnyoldalai. Infokommunikáció és Jog, 2013/2, 90.

${ }^{5}$ PATAKI Gábor Zsolt: Új technológiai kihívások az EU jogalkotásában. In: Homicskó Árpád Olivér (szerk.): Technológiai kihívások az egyes jogterületeken. Patrocinium, Budapest, 2018, 200. 


\section{A digitális hagyaték adatvédelmi megközelítése}

Felmerül a kérdés, hogy miként kell kezelni a személyes adatok hátramaradt halmazát, ha az örökhagyó nem megfelelően vagy egyáltalán nem rendelkezett azokról. Válaszként a nemzetközi jogirodalomban három különböző megközelítés született, attól függően, hogy a szerzők melyik jogterület - az adatvédelem, a kötelmi jog vagy a dologi jog - szabályait részesítik előnyben. A kérdést szükséges lenne megnyugtatóan rendezni, hiszen az elhunyt személyek személyes adatainak nem megfelelő kezelése hátrányos következményekkel járhat az adatalany emlékére vonatkozóan, valamint az életben lévő hozzátartozók jogaira és szabadságaira nézve is. Ez az oltalom ugyanakkor nem létezhet korlátok nélkül, a jogbiztonság és kiszámíthatóság érdekében időbeli keretek közé szükséges szorítani. Az elhunyt személy érdekei és az érdekek jelentősége ugyanis idővel elhalványulnak. ${ }^{6}$

\subsection{A szabad felhasználású adat megközelítés}

Ha a szerződések jogára hagyatkozunk, az adatkezelők jogosultak az elhunyt személyek személyes adatait megőrizni és továbbra is kezelni, az adatkezelő szerződési feltételei vagy a felek közös megállapodása szerint. Mindazonáltal, figyelemmel arra a tényre, hogy az adatalany elhunyt személy, az adatvédelmi előírások már nem relevánsak az adatkezelőre, ennek megfelelően ebben a megközelítésben abszolút semmilyen korlát vagy tilalom nincs a személyes adatok felhasználására vonatkozóan. Ez a megközelítés nem biztosít a felhasználók magánszférájának megfelelő védelmet a halál után, mivel a felhasználási feltételeket a szolgáltató adatkezelők határozzák meg, így azokban az adatkezelők érdekei dominálnak, vagyis valószerütlen, hogy az elhunyt személyek személyes adatainak védelmét kívánnák előnyben részesíteni.

További adatvédelmi szempontú veszélyt hordoz magában, ha az adatkezelők a halál tényének ismeretében folytatják az elhunyt személy adatait kezelő tevékenységet, és az elhunyt kapcsolatait felhasználva további gazdasági előnyre kívánnak szert tenni (ide értve különösen marketing hirdetések elhelyezését a gyászolók számára). Ezen túlmenően bizonyos típusú személyes adatok hatással lehetnek az elhunyt személy hozzátartozóira is: például az egészségügyi adatok vagy a genetikai adatok, amelyek vonatkozásában másodlagosan a hozzátartozók is érintettek lehetnek.

Ebben a kötelmi jogi megközelítésben dogmatikai vitát képezhet, hogy az egyik fél halála megszünteti-e az adatkezelést is magában foglaló szerződést. A magyar Nemzeti Adatvédelmi és Információszabadság Hatóság (NAIH) online adatok halál utáni kezelésére vonatkozóan kiadott korábbi ajánlásában (a továbbiakban: NAIH ajánlás) ${ }^{7}$ a hazai polgári jogi rendelkezéseket szem előtt tartva arra az álláspontra

${ }^{6}$ Smolensky, Kirsten Rabe: Rights of the Dead. Hofstra Law Review, 2009/3, 4.

7 A Nemzeti Adatvédelmi és Információszabadság Hatóság ajánlása az online adatok halál utáni sorsáról, 2015 november. https://www.naih.hu/files/Ajanlas_online-adatok-halal-utani-sorsarol.pdf (2021. 02. 12.). 
helyezkedett, hogy a halál ténye megszünteti a szerződéses kötelmet, és így az adatkezelő köteles törölni az előzőleg jogszerüen kezelt személyes adatokat.

\subsection{A személyes adatok dologként történő kezelése: a kvázi-tulajdon megközelítés}

A dologi jogi alapú megközelítés abból a tételből indul ki, hogy a személyes adatokat eszköznek vagy árucikknek, azaz dolognak kell tekinteni. Ez a megközelítés egyelöre azért problematikus, mert a digitális javak jogi mibenléte még nem tisztázott. ${ }^{8} \mathrm{~A}$ digitális hagyaték dologként való kezelése ahhoz vezethet, hogy az az elhunyt személy legközelebbi hozzátartozóihoz is kerülhet az öröklés során, amit esetleg az elhunyt személy nem kívánt.

A magyar polgári jog által alkalmazott dolog-fogalmat a Ptk. V. könyve tartalmazza, amely kimondja, hogy birtokba vehető testi tárgy tulajdonjog tárgya lehet. ${ }^{9}$ Ezen megfogalmazás alapján tehát dolognak kizárólag a birtokba vehető testi tárgyak minősülhetnek. ${ }^{10} \mathrm{~A}$ magyar szabályozásban a digitális módon rögzített - akár személyes - adatok tehát semmiképp sem tartozhatnak a dolog fogalmába, s így a személyes adatok bizonyos körére vonatkozóan a kvázi-tulajdon megközelítés csak anynyiban értelmezhető, amennyiben vagyoni értékű jogról, s nem dologról beszélünk.

Fontos ugyanakkor hangsúlyozni, hogy a digitális adatok nem csak fizikai mibenlétüket tekintve különböznek a dologtól, mint kézzel fogható testi tárgytól. A digitális személyes adatok alapján ugyanis lényegesen több információ derülhet ki az elhunyt természetes személyről, és azok lényegesen időtállóbbak is, mivel nem a fizikai térben léteznek, valamint könnyebb másokkal is megosztani azokat, s ezáltal kezelésük könnyebben válhat jogsértővé.

\subsection{A halál utáni személyiségvédelem megközelítése}

A harmadik megközelítés abból indul ki, hogy az adatalany privátszférája védelemre szorul még a halála után is, vagyis a személyes adatok akkor is léteznek és védelemre szorulnak, ha az alanyuk már elhalálozott. A magánszféra védelmének joga az emberi méltóságon és autonómián alapul, kérdéses ugyanakkor, hogy az emberi méltóság a halál után is fennmaradhat-e. A magyar alkotmánybírósági gyakorlat szerint az élet és emberi méltóság együtt jár és egymástól elválaszthatatlan egységet képez, oszthatatlan és korlátozhatatlan alapjogokként minden mást megelőző legnagyobb érték. ${ }^{11}$ Hazai polgári jogi szabályozásunk dogmatikájától idegen, hogy a személyiségi jogok „túléljék” alanyukat, a halott embernek nem lehet sem

${ }^{8} \mathrm{CHU}$, Natasha: Protecting Privacy after Death. Northwestern Journal of Technology and Intellectual Property, 2015/2, 255-275.

${ }^{9}$ Ptk. 5:14. §.

${ }^{10}$ Boóc Ádám: A dologi jog legfontosabb technológiai jogi kérdései, új technológiák joga és a dologi jog. In: Homicskó Árpád Olivér (szerk.): A digitalizáció hatása az egyes jogterületeken. Patrocinium, Budapest, 2020, 29.

11 23/1990. (X. 31.) AB határozat, ABH 1990, 88. 
joga, sem kötelezettsége, s így alany nélküli jogról sem beszélhetünk. ${ }^{12} \mathrm{~A}$ kegyeleti jogok vonatkozásában is az elhunyt személy emlékének, jó hírnevének megsértése a túlélők érzelmeit, személyiségi jogait sérti, ${ }^{13}$ a kegyeleti jog így az élők személyiségi jogaként érvényesül, habár kétségtelenül az elhunytat is sértő magatartás elleni fellépés lehetőségét teremti meg.

Fontos megjegyezni, hogy a halál utáni magánszféra elismerésének és védelmének az elvi akadályokon kívül gyakorlati korlátai, illetve nehézségei is vannak. Az egyik ilyen korlát a sérelem problémája, hiszen egy nem létező személynél nem lehet sérelmet realizálni. A másik nehézséget az okozza, hogy a jogok gyakorlására vonatkozóan nincs megfelelő személy (actio personalis moritur cum persona ${ }^{14}$ ), hiszen személyiségi jogot érvényesíteni csak személyesen lehet. ${ }^{15}$

\section{Európai körkép - nemzeti megoldások}

Jelenleg Európában nincs egységes álláspont a személyes adatok halál utáni védelmével és kezelésével kapcsolatban. Az Európai Unióban közvetlen hatállyal alkalmazandó általános adatvédelmi rendelet ${ }^{16}$ (General Data Protection Regulation, a továbbiakban: GDPR) preambuluma kifejezetten rögzíti, hogy „a rendeletet nem kell alkalmazni az elhunyt személyekkel kapcsolatos személyes adatokra. A tagállamok számára lehetővé kell tenni, hogy az elhunyt személyek személyes adatainak kezelését szabályozzák." ${ }^{17}$ Egyes jogrendszerek már éltek ezen felhatalmazás alapján a jogalkotás lehetőségével, mások még nem.

\subsection{Németország}

A német szövetségi alaptörvény (Grundgesetz) tartalmazza azon rendelkezést, miszerint a személy személyiségét szabadon érvényesítheti az állammal és másokkal szemben. ${ }^{18}$ Ennek az általános személyiségi jognak a törvényi alapjait a német

12 Kecskés László-Körös András-MAKAl Katalin-Orosz Árpád-Osztovits András-Petrik Ferenc: Az új Ptk. magyarázata I-VI. HVG-ORAC, Budapest, 2013, 147.

${ }^{13}$ Osztovits András (szerk.): A Polgári Törvénykönyvröl szóló 2013. évi V. törvény és a kapcsolódó jogszabályok nagykommentárja I. Opten, Budapest, 2014, 311.

14 TÜBAité-StalauskienÉ, Asta: Data Protection Post-mortem. International Comparative Jurisprudence, 2018/2. https://www3.mruni.eu/ojs/international-comparative-jurisprudence/article/view/4922 (2021. 02. 03.).

${ }^{15}$ MALgIERI, Gianclaudio: R.I.P.: Rest in Privacy or Rest in (Quasi-)Property? - Personal data protection of deceased data subjects between theoretical scenarios and national solutions. In: Leenes, Ronald-van Brackel, Rosamunde-Gutwirth, Serge-De Hert, Paul (eds.): Data Protection and Privacy: The Internet of Bodies. Hart, Brussels, 2018, 300-320. (doi: 10.5040/9781509926237.ch-006)

${ }^{16}$ Az Európai Parlament és a Tanács (EU) 2016/679 rendelete (2016. április 27.) a természetes személyeknek a személyes adatok kezelése tekintetében történő védelméről és az ilyen adatok szabad áramlásáról, valamint a 95/46/EK rendelet hatályon kívül helyezéséről (általános adatvédelmi rendelet). HL L 119., 2016.5.4., $1-88$.

17 GDPR Preambulum (27) bekezdés.

${ }^{18}$ Grundgesetz für die Bundesrepublik Deutschland, 2. cikk. https://www.gesetze-im-internet.de/gg/ BJNR000010949.html (2020. 10. 19.). 
polgári törvénykönyvben szereplő névviseléshez való jog, valamint a szerzői müvekröl szóló törvény képmáshoz való joga adja, valamint az adatvédelmi törvény. A német jog szerint a személyiségi jogok a halállal megszünnek, de a kegyeleti jogok továbbra is védik az elhunyt személy emlékét - ami az alaptörvényben és a büntetö törvénykönyvben egyaránt szabályozva van.

A német adatvédelmi törvény (Bundesdatenschutzgesetz) ${ }^{19}$ nem tartalmaz rendelkezéseket az elhunyt személyek személyes adatainak kezelésére vonatkozóan, a német jogalkotó egyelőre szándékosan ${ }^{20}$ nem élt a GDPR preambulumában említett lehetőséggel. Bár az adatvédelmi törvény nem foglalkozik az elhunyt személyek személyes adatainak kezelésével, jelenleg egyes szektorális jogszabályok érintik ezt a kérdéskört.

A német alkotmánybíróság ugyanakkor elismerte az ún. postmortalem Persönlichkeitsrecht intézményét, amelyet a Grundgesetz 1. cikkében szereplő emberi méltóság jogából vezetett le. ${ }^{21}$ Fontos ugyanakkor megjegyezni, hogy ez a halál utáni személyiségi jog egyfajta kegyeleti jogot keletkeztet, azonban semmiképp sem terjed addig, hogy az adatvédelmi szabályozást is érintse. ${ }^{22}$

\subsection{Franciaország}

2016. október 7-én az elhunyt személyek adatainak kezelésére vonatkozóan a francia törvényhozás kiegészítette az adatvédelmi törvényt (Loi Informatique et Libertés) ${ }^{23}$ a GDPR felhatalmazása alapján, és bevezetett egy olyan új eljárást, amely lehetővé teszi az adatalanyok rendelkezését arra vonatkozóan, hogy hogyan kezeljék személyes adataikat haláluk után. Az egyének általánosságban tehetnek rendelkezést személyes adataik kezelésére, valamint specifikusan, egyes adatkezelésekre vonatkozóan is. Az általános rendelkezéseket a francia adatvédelmi hatóságnak (Commission Nationale de l'Informatique et des Libertés) küldheti meg az adatalany, amely ezekről nyilvántartást vezet, míg a specifikus rendelkezéseket külön az adatkezelők részére szükséges továbbítani.

Az általános és egyedi rendelkezésekkel az adatalany meghatározhatja azt a módot, hogy hogyan kezeljék személyes adatait halála után. Amikor a rendelkezés olyan adatok kezelését írja elő, amely harmadik személyek személyes adatait is tartalmazza (például internetes kommunikáció), akkor azt az adatvédelmi törvény szabályait szem előtt tartva kell végrehajtani.

\footnotetext{
${ }^{19}$ Bundesdatenschutzgesetz vom 30. Juni 2017 (BGBI. I S. 2097). https://www.gesetze-im-internet.de/bdsg_ 2018/ (2020. 10. 19.).

${ }^{20}$ HRUBE, Mandy: Datenschutz nach dem Tod: DSVGO-Rechte für Angehörige? Dr. Datenschutz, 2019. október 30. https://www.dr-datenschutz.de/datenschutz-nach-dem-tod-dsgvo-rechte-fuer-angehoerige/ (2020. 10. 19.).

${ }^{21}$ ZAKARIÁs Kinga: Az általános személyiségi jog a német Szövetségi Alkotmánybíróság gyakorlatában. Jogtudományi Közlöny, 2013/2, 73.

22 BECKER, Tim: Verstorbenendaten und die DSGVO. Anwalt.de, 2019. május 29. https://www.anwalt.de/ rechtstipps/verstorbenendaten-und-die-dsgvo_155692.html (2020. 10. 19.).

${ }^{23}$ Loi n 78-17 du 6 janvier 1978 relative à l'informatique, aux fichiers et aux libertés. https://www.cnil.fr/fr/la-loiinformatique-et-libertes (2020. 10. 19.).
} 
A rendelkező személy bármikor módosíthatja vagy visszavonhatja rendelkezését, illetve kijelölhet egy másik személyt, aki ezeket helyette megteszi. Amikor az illető elhunyt, ez utóbbi jogosult megismerni a rendelkezéseket, és kérni azok végrehajtását az érintett adatkezelőktől. Ilyen kijelölt személy hiányában az elhunyt örökösei jogosultak megismerni a rendelkezéseket, és végrehajtásukat az érintett adatkezelőktől kérni. Ezek a törvényi szabályok kógensnek minősülnek, azaz az adatkezelők felhasználási feltételeinek bármely olyan kikötése, ami a rendelkezési jog csorbítására lenne alkalmas, semmis a francia jogban.

Amennyiben az elhunyt személy nem rendelkezik kifejezetten az adatai kezeléséröl, akkor az örökösei jogosultak az adatvédelmi törvényben meghatározott jogokat gyakorolni. Az örökösök töröltethetik az elhunyt felhasználói fiókjait, tiltakozhatnak az elhunytat érintő személyes adatok további kezelése vagy feldolgozása ellen, vagy kérhetik azok módosítását, helyesbítését. Amennyiben több örökös van, és azok között nézeteltérés támad az elhunyt személyes adatainak kezelésére vonatkozóan, jogosultak bírósághoz fordulni a vita eldöntése érdekében.

Az elhunytakra vonatkozó információk, ideértve a halotti anyakönyvi kivonatokon feltüntetett információkat is, az egészségügy területén végzett kutatás, tanulmány vagy értékelés céljából kezelhetők és feldolgozhatók, kivéve, ha az érintett életében írásban kifejezetten tiltakozott ez ellen. ${ }^{24}$

Ez a megközelítés Európában az egyik leginkább elöremutató megoldás, hiszen az adatalanyok kifejezetten kinyilváníthatják a személyes adataik kezelésére vonatkozó akaratukat a haláluk utánra, így biztosított számukra az információs önrendelkezés és magánszférájuk védelme post mortem is.

\subsection{Svájc}

A svájci polgári törvénykönyv (Schweizerisches Zivilgesetzbuch, ZGB) a személyiségi jogok között nem tartalmazza a személyes adatok védelméhez való jogot. ${ }^{25}$ A svájci öröklési jog szerint a hagyaték mint egész száll át az örökösökre. ${ }^{26} \mathrm{Az}$ olyan digitális adatok, amelyek adathordozón szerepelnek, a hagyaték részét képezik a többi dologgal egyetemben, nincs azonban egyértelmű szabályozás az olyan adatokra vonatkozóan, amelyek az interneten vagy más hálózatokon találhatóak meg. Az interneten található adatok esetében már nem az öröklési jog alá eső dolgokról van szó, hanem személyiségi jogokról, amelyek a halállal nem szállnak át. ${ }^{27}$ A hozzátartozóknak emiatt csak korlátozott lehetőségeket ad a kegyeleti jog intézménye.

A svájci jogban ahhoz, hogy az információs önrendelkezési jog a halál után is biztosított legyen, az örökhagyónak a végakaratában rendelkeznie kell az adatok sorsáról, természetesen a végrendelkezés alakisági feltételeinek megfelelően. Ehhez

\footnotetext{
${ }^{24}$ A törvény 84-86. cikkei.

${ }^{25}$ Schweizerisches Zivilgesetzbuch vom 10. Dezember 1907. https://www.admin.ch/opc/de/classified-compilation/19070042/index.html (2020. 10. 19.).

${ }^{26}$ ZGB 560. cikk (1).

27 ZGB 31. cikk (1).
} 
elengedhetetlen ugyanakkor, hogy a felhasználói fiókok és az azokhoz tartozó jelszavak az örökösök rendelkezésére legyenek bocsátva. Amennyiben az örökhagyó nem akarja örököseire hagyni a személyes adatokat, igénybe veheti a Vererbungsdienst nevű szolgáltatást, amely során a digitális hagyatékot is kezeli a megbízott szervezet.

Mivel a személyiségi jogok a svájci jog szerint is megszűnnek a halállal, felmerül a kérdés, hogy az elhunyt személyek személyes adatai élveznek-e védelmet. A svájci adatvédelmi törvény (Bundesgesetz über den Datenschutz, DSG) ${ }^{28}$ úgy rendelkezik, hogy az elhunyt személyre vonatkozó adatokat ki kell adni, ha a kérelmező bizonyítja a jogi érdekét és nincs a hozzátartozóknak vagy más harmadik személyeknek ellenkező érdeke a kiadással szemben. A jogi érdeket megalapozza például a házasság. ${ }^{29}$ Egyes ágazati jogszabályok, mint az egészségügyi törvény, a banktörvény vagy a levéltitkokra vonatkozó szabályozás eltérhet ettől a rendelkezéstől. Az olyan múvek esetében, amelyek a szerzői jog hatálya alá tartoznak, a szerzői jogi védelem is biztosított, azonban az interneten publikált tartalmak csak ritkán merítik ki a svájci szerzői jog által támasztott kritériumokat. ${ }^{30}$

Svájcban a jogalkotó tehát a digitális hagyaték és a hátramaradt személyes adatok kérdéskörét elsődlegesen a polgári jog klasszikus részterületein - az öröklési jog, a dologi jog és a szerzői jog szabályaival - kívánta rendezni, az adatvédelmi jogot ezzel háttérbe szorítva.

\subsection{A hazai szabályozás}

Hazánkban az információs önrendelkezési jogról és információszabadságról szóló 2011. évi CXII. törvény (a továbbiakban: Infotv.) 2018-as módosítása ${ }^{31}$ a GDPR felhatalmazása alapján lehetővé tette az adatalanyok számára az információs önrendelkezést a halál utánra, a bevezetőben említett 2016-os NAIH ajánlás nyomán. A NAIH ajánlásában egyrészt ismertette a személyes adatok kezeléséhez kapcsolódó jogosultságoknak az adatalany halálát követő jogi sorsára vonatkozó akkori jogi rendelkezéseket, másrészt felhívta az igazságügyi minisztert, hogy „vizsgálja meg a lehetőségét egy olyan jogalap és eljárásrend kidolgozásának, amely [az ajánlásban megfogalmazott, a személyes adatokhoz kapcsolódó egyes jogosultságokkal] ruházná fel az elhunyt hozzátartozóit és örököseit az Infotv.-ben meghatározott alapelvek és elöírások minél teljesebb érvényesülésének megteremtése érdekében."32 A jogalkotó a NAIH ajánlásban foglaltaknak eleget téve kiegészítette az Infotv.-t a

\footnotetext{
${ }^{28}$ Bundesgesetz über den Datenschutz vom 19. Juni 1992. https://www.admin.ch/opc/de/classified-compilation/19920153/index.html (2020. 10. 19.).

${ }^{29}$ DSG 1. cikk (7).

${ }^{30}$ Eidgenössischer Datenschutz- und Öffentlichkeitsbeauftragter: Digitales Erbe. https://www.edoeb.admin.ch/ edoeb/de/home/datenschutz/Internet_und_Computer/onlinedienste/digitales-erbe.html (2020. 10. 19.).

${ }^{31}$ Az érintett halálát követően a személyes adatokkal összefüggő jogok érvényesítésére vonatkozó rendelkezéseket a 2018. évi XXXVIII. törvény 10. §-a iktatta be az Infotv.-be, amely módosítás 2018. július 26-tól hatályos.

${ }^{32} \mathrm{NAlH}$ ajánlás 9 .
} 
25. § beillesztésével, amely az adatalany információs önrendelkezési jogát biztosítja első sorban.

A hatályos törvényi szabályozás szerint az érintett halálát követő öt éven belül a hozzáférés, helyesbítés, törlés és korlátozás jogát, illetve a tiltakozáshoz való, az elhaltat életében megillető jogokat az érintett által arra ügyintézési rendelkezéssel, illetve közokiratban vagy teljes bizonyító erejű magánokiratban foglalt, az adatkezelőnél tett nyilatkozattal - ha az érintett egy adatkezelönél több nyilatkozatot tett, a későbbi időpontban tett nyilatkozattal - meghatalmazott személy jogosult érvényesíteni. ${ }^{33} \mathrm{Ha}$ az érintett nem tett ilyen jognyilatkozatot, a Ptk. szerinti közeli hozzátartozója ${ }^{34}$ annak hiányában is jogosult a helyesbítés és tiltakozás jogát, valamint - ha az adatkezelés már az érintett életében is jogellenes volt vagy az adatkezelés célja az érintett halálával megszűnt - az elhaltat életében megillető törlés és korlátozás jogát érvényesíteni az érintett halálát követő öt éven belül. Az érintett jogainak érvényesítésére az a közeli hozzátartozó jogosult, aki ezen jogosultságát elsőként gyakorolja.

Az érintett jogait érvényesítő személyt a jogok érvényesítése során - így különösen az adatkezelővel szembeni, valamint a NAlH, illetve bíróság előtti eljárásban az Infotv. által az érintett részére megállapított jogok illetik meg és kötelezettségek terhelik. ${ }^{35}$ Tehát „az egyes érintetti jogokat érvényesítő személyek jogosultságai - a nemo plus iuris alapelvvel összhangban - az Infotv. alapján az érintettet ezen jogok érvényesitése során megillető jogosultságok tartalmához, azok gyakorlásának feltételeihez, korlátaihoz igazodnak."36

A törvény „mind az érintett akaratnyilatkozatán, mind a törvényi rendelkezésen alapuló jogosultságok érvényesithetőségét a jogrendszerben széles körben alkalmazott mértékü, objektív időbeli korláthoz (az érintett halálát követő öt év) köti. Ezzel megfelelő egyensúlyt teremt az érintett személyes adatainak a halálát követő rendezéséhez füződő, valamint az adatkezelők adminisztratív terheinek észszerü mértékéhez füződő érdekek között." ${ }^{37}$ A kötelmi jellegủ viszony értelemszerủen a Ptk.-ban foglalt általános elévülési időn belül gyakorolható.

Amennyiben megvizsgáljuk a NAlH ajánlásban és az igazságügyminiszternek szóló felhívásban foglalt követelményeket, azt láthatjuk, hogy a jogalkotó az ajánlásban megfogalmazott kívánalmakat maradéktalanul teljesítette, kiegészítve azokat olyan rendelkezésekkel, amelyek az információs önrendelkezési jogot előtérbe helyezték.

A NAlH ajánlásnak megfelelően a Ptk. szerinti közeli hozzátartozó kérheti az elhunyt felhasználói fiókjának törlését, ezzel biztosítva az adatminimalizálás és a célhoz kötött adatkezelés elveinek érvényesülését. Az Infotv. módosítása ezen felül messzemenőkig biztosítja az elhunyt önrendelkezési jogát azzal, hogy az ajánlásban foglaltakon túlmenően elsődlegesen az elhunyt által meghatalmazott személy részére teremtette meg az eljárási jogosultságot.

${ }^{33}$ Infotv. 25. §(1).

${ }^{34}$ A Ptk. 8:1. § (1) bekezdése szerint „1. közeli hozzátartozó: a házastárs, az egyeneságbeli rokon, az örökbefogadott, a mostoha- és a nevelt gyermek, az örökbefogadó-, a mostoha- és a nevelőszülő és a testvér."

35 Infotv. 25. § (3).

36 T/623. számú törvényjavaslat az információs önrendelkezési jogról és az információszabadságról szóló 2011. évi CXII. törvénynek az Európai Unió adatvédelmi reformjával összefüggő módosításáról, valamint más kapcsolódó törvények módosításáról (2018 június, a továbbiakban: Indokolás) Indokolás a 10. §-hoz.

37 Indokolás a 10. §-hoz. 
A szabályozás nem terjeszti ki az elhunyt személyt megillető, az Infotv. és a GDPR által garantált jogokat a hozzátartozókra és örökösökre, kifejezetten szűkebb lehetőségeket teremt a hozzátartozók számára. Ezáltal a szabályozás a személyiségi jogok és a személyes adatok védelmének társadalmi céljával maximálisan összeegyeztethető.

A jogalkotó a módosítással olyan új, törvényen alapuló jogalapot teremtett, amely az egyes szolgáltatásokhoz kapcsolódó, az érintett hozzájárulásán alapuló adatkezeléseknél az elhunyt adatalannyal kapcsolatban kezelt adatok megsemmisítésére, törlésére irányuló felhívás jogával ruházza fel a hozzátartozókat, illetve örökösöket. Fontos ugyanakkor hangsúlyozni, hogy a GDPR-ral a jogalapok rendszere is kibövült a korábbi dualista rendszerhez képest, amely alapján személyes adatot kezelni kizárólag törvény rendelkezése vagy az érintett hozzájárulása alapján lehetett. Az új Infotv.-beli szabályozás ennek megfelelően már nem csak a hozzájáruláson alapuló korábbi adatkezelések vonatkozásában teremtette meg a közeli hozzátartozó vagy meghatalmazott személy joggyakorlási lehetőségét, hanem minden, a GDPR hatálya alá tartozó adatkezelés vonatkozásában.

Létrejött a joggal való visszaélés lehetősége kizárásának törvényi alapja is, így az eljáró személyek jogukat kizárólag a hozzátartozói/örökösi minőség, illetve az érintett halálának hitelt érdemlő igazolása mellett gyakorolhatják. Az örökösi minőség igazolására alkalmas a közjegyző által kiállított öröklési bizonyítvány vagy a jogerős hagyatékátadó végzés. Az érintett halálának tényét és idejét halotti anyakönyvi kivonattal vagy bírósági határozattal, valamint az eljáró személy saját személyazonosságát, közeli hozzátartozói minőségét közokirattal köteles igazolni. ${ }^{38}$

A jogalkotó tehát a NAIH követelményeinek megfelelően, a teljes jogbiztonság megteremtése érdekében további elöremutató rendelkezéseket is beépített, kiterjesztve az elhunyt személy információs önrendelkezési jogát.

Bár az Infotv. európai viszonylatban kiemelkedően haladó szellemben emeli ki az önrendelkezés szerepét a személyes adatok halál utáni védelme során, az önrendelkezési nyilatkozatok kezelésére vonatkozóan a központosított hatósági hátteret (amelyre különösen a francia szabályozásban találhatunk példát) nem teremtette meg, azt az adatkezelők feladataként határozza meg, amivel azonban széttöredezetté teszi az adatok védelmét. Ez gyakorlatilag jogszabályba foglalja azt a védelmet, amelyet egyes magán adatkezelők már korábban is biztosítottak. ${ }^{39} \mathrm{Az}$ Infotv.ben foglalt rendelkezések továbbá kizárólag az adatkezelővel ${ }^{40}$ szemben érvénye-

\footnotetext{
38 Infotv. 25. § (4).

${ }^{39}$ A Facebook például már 2009 óta lehetővé teszi a felhasználók profiljainak emléklappá való nyilvánítását, valamint 2015 óta hagyatéki kapcsolattartó kijelölését. A Google is lehetővé teszi, hogy az örökösök az elhunyt személy fiókjával kapcsolatos kérelmet nyújtsanak be hozzá, amely keretében lehetőséget kínál a fiók lezárására, kérelem benyújtására a fiókban lévő javakra vonatkozóan, valamint adatok lekérésére a fiókból. A Twitter szabályzata szerint az elhunyt személy igazolt családtagja vagy meghatalmazott képviselője eljárhat a hozzáférés deaktiválása érdekében.

${ }^{40}$ GDPR 4. cikk „7. adatkezelö: az a természetes vagy jogi személy, közhatalmi szerv, ügynökség vagy bármely egyéb szerv, amely a személyes adatok kezelésének céljait és eszközeit önállóan vagy másokkal együtt meghatározza; ha az adatkezelés céljait és eszközeit az uniós vagy a tagállami jog határozza meg, az adatkezelöt vagy az adatkezelö kijelölésére vonatkozó különös szempontokat az uniós vagy a tagállami jog is meghatározhatja."
} 
síthetők, adatkezelőnek nem minősülő személyek általi esetleges jogsértés esetén a kegyeleti jog intézménye alkalmazandó.

\section{A digitális hagyaték öröklési jogi szempontú vizsgálata}

A digitális hagyaték vizsgálata során - lévén, hogy a személyes adatok akár vagyoni értéket is képviselhetnek - szükséges az öröklési jog szabályait is szem előtt tartanunk és megemlítenünk, a teljeskörü bemutatás igénye nélkül. A hatályos Ptk. szerint az ember halálával hagyatéka mint egész száll az örökösre. ${ }^{41}$ Az örökölhető javak körét egy adott társadalom tulajdoni rendje határozza meg, és ennek függvénye az öröklés rendje is, amely szabályozza, hogy a javak a tulajdonos halálát követően milyen szabályok szerint, kire szállhatnak át. Bár az öröklési jog nem tesz különbséget digitális és analóg világ között, így a hagyaték elemeit sem tekinthetjük digitális és egyéb hagyatéknak, ${ }^{42}$ ugyanakkor a hagyatéki elemek jogi megítélése további vizsgálatot tesz szükségessé. A digitális hagyaték egy gyűjtőfogalom, amely az örökhagyó különböző jogait és jogviszonyait öleli fel. ${ }^{43}$

A hagyaték az örökhagyót a halálakor megillető polgári jogi jellegű vagyoni jogok és kötelezettségek egésze. Ebböl következően nem tartoznak az örökhagyó hagyatékába a polgári jogi jellegü, de nem vagyoni - személyhez füződő - jogok és kötelezettségek, de azok a polgári jogi vagyoni jellegü jogok sem, amelyek az örökhagyót az élete végéig illetik meg (például tartási jog, haszonélvezeti jog). ${ }^{44} \mathrm{~A}$ magyar öröklési jog szabályai szerint tehát kizárólag a digitális hagyatékba tartozó olyan adatok öröklődnek, amelyek vagyoni értékkel bírnak és nem személyhez füződőek - így például a hagyaték részét képezik az elhunyt online előfizetései, bitcoin egyenlege, nagy látogatottságú honlapjai. Nem képezik ugyanakkor az öröklés tárgyát azon személyes adatok halmazai, amelyek személyhez füződnek - így például e-mail fiókok, közösségi média hozzáférések. A személyes adatokra a dologi jogi szabályok értelemszerüen nem vonatkoznak, mivel nem minősülnek birtokba vehető testi tárgynak, s így dolgok módjára sem öröklődhetnek (ide nem értve az esetleges adathordozót, amely már dolognak minősül, és így öröklés tárgya lehet).

A digitális hagyatékba tartozó adatok tehát heterogenitásukból adódóan nem kezelhetők egységesen az öröklési jog szabályai szerint. A Ptk. szabályaitól függetlenül ugyanakkor a favor testamenti elv alapján semmi akadálya nincs annak, hogy az örökhagyó még életében végakaratába foglalja, hogy ki és milyen módon jogosult kezelni a halála után hátramaradt személyes adatok halmazát. Érdekes helyzet lehet - bár előfordulása nem valószínű -, ha az örökhagyónak az Infotv. 25. § szerinti adatkezelőnél tett nyilatkozata és a végrendeletbe foglalt rendelkezése eltér egymástól, így kérdésessé válik, melyik élvez elsőbbséget. Erre megoldást nyújthat az az elv, hogy a később tett nyilatkozat felülírja a korábbit, de lehet érvelni amellett is,

\footnotetext{
${ }^{41}$ Ptk. 7:1. §.

42 RÉDLING Beáta: Digitális kor - digitális hagyaték. Közjegyzők Közlönye, 2020/2, 28.

${ }^{43}$ RÉDLING: i. m., 29.

${ }^{44}$ KECSKÉS-KŐRÖS-MAKAI-OROSZ-OSZTOVITS-PETRIK: i. m., 147.
} 
hogy a végrendeletek végrehajtására kialakult jogi rendszer alkalmasabb az érintett tényleges akaratának biztosítására, ezért a végrendeleti nyilatkozatnak kellene elsőbbséget élveznie.

Meglátásom szerint tehát az Infotv.-ben szabályozott, adatkezelőnél letett nyilatkozat helyett szükség lenne egy francia mintára létrehozott közhiteles nyilvántartásra, a Magyar Országos Közjegyzői Kamara által vezetett Végrendeletek Országos Nyilvántartása analógiájára. A közhiteles nyilvántartás vezetésére véleményem szerint leginkább a MOKK vagy a NAIH lenne a legalkalmasabb. A MOKK általi vezetést indokolná, hogy a hagyatéki eljárásban, ahol a személyes adatokról szóló rendelkezés is felmerülhet (például vagyoni vonatkozásai miatt), azonnal az eljárást lefolytató közjegyző rendelkezésére állna a szükséges dokumentum. A NAlH általi vezetést az indokolná, hogy a tisztán a személyhez kapcsolódó adatok védelme az adatvédelmi hatóság hatáskörébe tartozik.

\section{A digitális hagyaték személyiségi jogi aspektusa}

Végezetül, de nem utolsó sorban az elhunyt kegyeleti jogainak vonatkozásában is szükséges megvizsgálni a hátramaradt digitális személyes adatok halmazát.

Az ember halálával a személyiség is véget ér, a személy megszünik jogok és kötelezettségek alanya lenni. Ez a tiszta, elvi álláspont, amely évtizedekre meghatározta a kegyeleti jog tartalmát, egyre nehezebben érvényesíthető napjainkban, amikor a személyiségvédelem egyre szélesebb körü. Az ember nem nyomtalanul múlik el, részben az anyagi világban, részben mások emlékezetében továbbél, ${ }^{45}$ s a technológiai fejlödésnek köszönhetően a digitális világban is megmarad egy része. Bár a halállal a személyiség véget ér, annak társadalmi hatása nem szúnik meg azonnal, ${ }^{46}$ és e társadalmi hatás jogi védelmet élvez. A jogalkotó a polgári jog keretein belül a kegyeleti jog intézményével biztosítja ezt az oltalmat.

Magától értetődően a személyiség halál utáni védelme nem ugyanolyan körben és módon lehetséges, mint a személy életében. Vannak olyan jogok, amelyek az elhalálozást követően jelentés nélkülivé válnak, de vannak olyanok is, amelyek a halál után is releváns értékeknek tekintendők. ${ }^{47} \mathrm{Az}$ elhalt emlékének védelme biztosított minden olyan emberi magatartással szemben, amely sérti az elhalt személy emlékének épségben történő megőrzését, az elhalt életmúvének, hatásának, alkotásainak háborítatlan továbbélését az élők tudatában. Ennek a védelemnek a tárgyai elsősorban a személyes titok, a személyes adatok, a név, a jó hírnév, a becsület, az emberi méltóság, a képmás és hangfelvétel, továbbá a szellemi alkotás. ${ }^{48}$

A hatályos Ptk. szerint „meghalt ember emlékének megsértése miatt bírósághoz fordulhat a hozzátartozó vagy az, akit az elhunyt végrendeleti juttatásban részesített."

\footnotetext{
${ }^{45}$ PETRIK Ferenc: A személyiség jogi védelme és a sajtó-helyreigazitás. HVG-ORAC, Budapest, 2001, 179.

${ }^{46}$ GöRög Márta: A kegyeleti jog és a nem vagyoni kártérités. Pólay Elemér Alapítvány, Szeged, 2008, 17.

${ }^{47}$ GöRÖG: i. m., 11.

48 TÖRö Károly: Személyiségvédelem a polgári jogban. Közgazdasági és Jogi Könyvkiadó, Budapest, 1979, 683.

${ }^{49}$ Ptk. 2:50. §.
} 
A Ptk. az emléket megsértő magatartásról szól, azonban ez nem csak a jóhírnévhez füződő jog megsértését jelenti. Bár az elhunytnak nincs személyisége, mégis emléke, jó híre és társadalomra gyakorolt hatása sajátos módon tovább él környezetében. A személyiség posthumus védelmét a bírói gyakorlat dolgozta ki, ${ }^{50}$ amely értelmében a meghalt személy emlékének megőrzését a jó hírnevének, becsületének, emberi méltóságának, magántitkainak és személyes adatainak, továbbá valós gondolatainak, szerzői jogainak ${ }^{51}$ a védelme szolgálja leginkább. ${ }^{52}$

Nagyon fontos megemlíteni, hogy a Ptk. által szabályozott egyes személyiségi jogok között átfedés van a hátrahagyott (akár digitális, akár egyéb módon rögzített) személyes adatok vonatkozásában. Például személyes adatnak minősül egy Facebookon megosztott fénykép, ugyanakkor nemcsak a személyes adat védelméhez füződő jog, hanem a képmáshoz való jog sérelmét is jelenti, ha valaki jogellenesen felhasználja azt. Az internetes levelezések - így különösen, de nem kizárólagosan az e-mailek, chat beszélgetések - harmadik személyek általi megismerése sérti a magántitokhoz, levéltitokhoz való jogot, de ugyanúgy kiterjed rá a személyes adatok védelme is. Mindenképp szem előtt kell tartani a digitális hagyatékkal való rendelkezés során, hogy bizonyos esetekben a digitális hagyaték más, még élő személyek személyiségi jogait, különösen levéltitkát is érintheti. Egy ilyen összeütközés esetén a bíróságnak állást kell foglalnia abban a kérdésben, hogy melyik élvez elsőbbséget: az elhunyt személy személyes adatainak védelme, a hozzátartozók jogilag releváns igénye a tartalmak megismerésére, az azokkal való rendelkezésre, vagy a túlélő harmadik személy személyiségi jogai.

Felmerül az a kérdés is a jelszóval védett tartalmak esetében, hogy ha az elhunyt személy életében nem hozta mások tudomására a jelszavát, tekinthető-e úgy, hogy a tartalmak megsemmisítését kívánta. Ha a halála utánra kifejezetten nem rendelkezett a tartalmak megismerhetőségéről, nem kell-e vélelmezni, hogy azokat titokban kívánta tartani? A kérdések megválaszolása nem egyszerü, mivel nem valószínű, hogy ha az ember életében titokban kívánja tartani ezeket az adatokat, a halála utáni időpontra már azok megosztását, nyilvánosságra kerülését, öröklését kívánná. ${ }^{53}$

A túlélő levéltitka, az elhunyt személy adatainak védelme és a hozzátartozók megismerési igénye kollíziójának feloldására vonatkozóan hazánkban még nem született bírósági döntés. Németországban azonban a Szövetségi Legfelső Bíróság (Bundesgerichtshof) 2018-ban úgy határozott, ${ }^{54}$ hogy egy közösségi médiaplatform felhasználói fiókja öröklődik, ezáltal a szolgáltatás üzemeltetője köteles a felhasználói

\footnotetext{
${ }^{50}$ BÉKESI Nóra: A temetkezési jog magánjogi vetülete. In: Kosza Yvette (szerk.): A temetkezéssel kapcsolatos szabályozás: tudományos konferencia (Budapest, 2004. március 19.). Károli Gáspár Református Egyetem Állam- és Jogtudományi Kar, Budapest, 2005, 19.

${ }^{51}$ LANDI Balázs: Az emberi méltóság, mint polgári jogi személyiségi jog az emberi élet ellenében, sőt azon is túl? Gondolatok a halál és a kegyeleti jog kapcsán. Iustum Aequum Salutare, 2020/2, 68.

52 BH 1996. 250.

${ }^{53}$ Cummings, Rebecca G.: The Case Against Access to Descendents' E-mail: Password Protection as an Exercise of the Right to Destroy. Minnesota Journal of Law, Science \& Technology, 2014/2, 897-947.

${ }^{54}$ Bundesgerichtshof III. ZR 183/17 (Nr. 115/201). http://juris.bundesgerichtshof.de/cgi-bin/rechtsprechung/ document. py? Gericht=bgh\&Art=pm\&Datum=2018\&Sort=3\&nr=85390\&pos=0\&anz=115 (2020. 09. 27.).
} 
fiókhoz kapcsolódó kommunikációt kiadni az örökösök számára. Az ügyben egy 15 éves lány elhalálozása után a szülei fordultak egy olyan közösségi médiaszolgáltatóhoz, amely a felhasználói számára interneten keresztüli kommunikációt és tartalommegosztást szolgáltat. Az akkor 14 éves elhunyt 2011-ben regisztrált az oldalon szülői beleegyezéssel, majd 2012-ben tisztázatlan körülmények között elhunyt egy metróbalesetben. A szülők ezek után megkíséreltek lányuk felhasználói fiókjába bejelentkezni, azonban ez a próbálkozás nem járt sikerrel, mivel a felhasználói fiók időközben emléklappá lett nyilvánítva, ezáltal a felhasználói fiókhoz tartozó tartalmak már nem voltak elérhetőek, a szolgáltató azonban még rendelkezett azokkal. A szülők pert indítottak a szolgáltató ellen a felhasználói fiókhoz tartozó kommunikáció kiadása iránt, hogy megállapítható legyen, az elhunyt lány öngyilkosságot követett-e el, vagy fennáll a metróvezető kártérítési felelőssége. A bíróság megállapította, hogy a felhasználói fiókra vonatkozó szerződés nem személyhez kapcsolódó, és ezáltal örökölhető. A bíróság kiemelte, hogy az analóg dokumentumok, mint naplók vagy személyes levelek dologként öröklődnek, így a digitális tartalmakat sem szükséges másképp kezelni. A bíróság nem fogadta el azt az érvet, hogy a post mortem személyiségvédelem miatt kizárt lenne az öröklődés, továbbá azt sem, hogy a döntés ellentétes lenne a személyes adatok védelmére vonatkozó szabályozással, mivel személyes adatai a német jog szerint kizárólag élő természetes személyeknek vannak.

\section{5. Összegzés}

Összefoglalóan elmondhatjuk, hogy jelenlegi, hálózatokkal átszőtt társadalmunkban (network society) a hagyaték részeként megjelentek olyan új elemek, amelyeknek az öröklés esetén felmerülő jogi megítélése okot ad az elmélkedésre. ${ }^{55}$ Ezen elemek jogi sorsának rendezéséhez - figyelemmel arra, hogy a magyar öröklési szabályok szerint nem öröklődhetnek - több jogterületet kell segítségül hívnunk, mivel komplexitásuk miatt a korábban kialakult magánjogi dogmatikában nem kezelhetők. Ezért tartalmazza a hátramaradt, nem vagyoni jellegü, hanem személyiségi jellegű személyes adatok védelmét a közigazgatási típusú adatvédelmi jog, biztosítva az egyén legszélesebb körü önrendelkezési jogát. Bár az Infotv. 2018-as módosítása ${ }^{56}$ kétségkívül közelebb vitte a magyar jogrendszert ahhoz, hogy az elhunytak személyes adatainak védelmén keresztül az elhunyt személyisége is védelemben részesüljön, és a digitális hagyaték sorsát rendezni lehessen, a magánjogi jogterületek nem idomultak még teljes körüen ehhez az új kihíváshoz.

Az Infotv. nem teremtette meg a központosított hatósági hátteret a nyilatkozatok kezelésére vonatkozóan, azt az adatkezelőkre bízta, ami azonban megnehezíti a jogérvényesítés lehetőségét, különösképpen akkor, ha a későbbi jogérvényesítésre

\footnotetext{
${ }^{55}$ Boóc Ádám: Technológiai kihívások a polgári jogban, különös tekintettel az öröklési jogra. In: Homicskó Árpád Olivér (szerk.): Technológiai kihivások az egyes jogterületeken. Patrocinium, Budapest, 2018, 25.

${ }^{56}$ 2018. évi XXXVIII. törvény 10. §.
} 
jogosult személy - akár meghatalmazott, akár közeli hozzátartozó - a nyilatkozat létéről nem is bír tudomással, s így az adatkezelő sem szerezhet tudomást a halál tényéről. A jogérvényesítési nehézség ezen problémáját egy központi nyilvántartás létrehozása kiküszöbölhetné, amelyre vonatkozóan a törvény nem tartalmaz rendelkezést.

Szükséges lenne továbbá összehangolni az információs önrendelkezés és az adatvédelem dogmatikáját, illetve az öröklési jogi anyagi és eljárási szabályokat, és kialakítani egy olyan eljárásrendet, amely hatékonyan tudja biztosítani az elhunyt személy védelmét. 